\title{
BEBERAPA FAKTOR YANG MENYEBABKAN KEMISKINAN NELAYAN DI GUGUS KEPULAUAN SALABANGKA KECAMATAN BUNGKU SELATAN KABUPATEN MOROWALI PROVINSI SULAWESI TENGAH
}

\section{SOME FACTORS CAUSING POVERTY OF FISHERMEN IN SALABANGKA ISLANDS CLUSTER BUNGKU SELATAN DISTRICT MOROWALI DISTRICT CENTRAL SULAWESI PROVINCE}

\author{
Nurdin Lanuhu \\ Departemen Sosial Ekonomi Pertanian, Fakultas Pertanian, Universitas Hasanuddin \\ Diterima: 10 September 2018; Disetujui: 20 September 2018
}

\begin{abstract}
ABSTRAK
Penelitian ini dilaksanakan di Gugus Kepulauan Salabangka Kecamatan Bungku Selatan Kabupaten Morowali Propinsi Sulawesi Tengah, pada bulan Juli 2016 sampai dengan Agustus 2016. Lokasi penelitian dipilih secara purposif dengan pertimbangan bahwa Gugus Kepulauan Salabangka Kecamatan Bungku Selatan Kabupaten Morowali penduduknya umumnya bermata pencaharian sebagai nelayan dan memiliki jumlah penduduk miskin yang terbanyak di Kabupaten Morowali. Penelitian ini bertujuan melakukan kajian terhadap faktor-faktor penyebab kemiskinan di Gugus Kepulauan Salabangka Kecamatan Bungku Selatan Kabupaten Morowali Provinsi Sulawesi Tengah. Sementara kegunaan yang diharapkan alam penelitian adalah tersedianya data dan informasi factor- factor penyebab kemiskinan yang dapat digunakan oleh berbagai pihak dalam menyusun model pemberdayaan masyarakat nelayan dalam penenggulangan kemiskinan di Kabupaten Morowali. Penelitian ini didesain dengan menggunakan mixed method approach, dengan menggabungkan Quantitative and Qualitative Research Designs secara simultan. Sedangkan Qualitative Research Design menggunakan metode Focus Group Discussion (FGD). Pendekatan ini dilakukan untuk memperoleh data dan informasi yang komprehensif dan saling melengkapi, sehingga situasi riel di lapangan dapat dideskripsikan dengan baik. Adapun proses tahapan penelitian ini adalah Review literature, Kunjungan Lapangan, Uji kuisioner dan FGD, pengumpulan data primer dan sekunder. Hasil Penelitian menunjukkan bahwa beberapa faktor yang mennyebabkan kemiskinan di Gugus Kepulauan Salabangka Kecamatan Bungku Selatan Kabupaten Morowali Provinsi Sulawesi Tengah adalah Keadaan Musim, Struktur Sosial, Pengelolaan Pendapatan, Pencemaran Lingkungan dan Pelayanan Pemerintah dibidang pemerintahan, pendidikan, kesehatan dan sarana prasarana tranportasi.Guna mengentaskan kemiskinan maka direkomendasikan 1) Pengembangan ekonomi kerakyatan berbasis potensi lokal, 2) Perbaikan pelayanan pemerintah dalam bidang pemerintahan, pendidikan, kesehatan dan penyediaan sarana transportasi laut.
\end{abstract}

Kata Kunci : Nelayan, Kemiskinan, Pulau

\section{ABSTRACT}

This research was conducted at Salabangka Island Cluster of South Bungku District, Morowali Regency, Central Sulawesi Province, from July 2016 until August 2016. The location of the study was chosen purposively with consideration that Salabangka Island Cluster of South Bungku Sub-district of Morowali Regency generally have livelihood as fisherman and have number the poorest people in Morowali District. This study aims to 
study the factors causing poverty in the Salabangka Islands cluster in South Bungku District, Morowali District, Central Sulawesi Province. While the expected usefulness of the nature of research is the availability of data and information factors - factors causing poverty that can be used by various parties in developing a model of community empowerment of fishermen in poverty alleviation in Morowali District. This research was designed by using mixed method approach, by combining Quantitative and Qualitative Research Designs simultaneously. While Qualitative Research Design uses Focus Group Discussion (FGD) method. This approach is done to obtain comprehensive and complementary data and information, so that real situation in the field can be well described. The process of this research stages is Review literature, Field Visit, Questionnaire Test and FGD, primary and secondary data collection. The results of the research indicate that several factors causing poverty in the Salabangka Islands cluster in South Bungku District, Morowali Regency, Central Sulawesi Province are the Season Condition, Social Structure, Revenue Management, Environmental Pollution and Government Service in the field of government, education, health and transportation facilities.Guna eradicate poverty it is recommended 1) Development of local people-based economic potential, 2) Improvement of government services in the areas of government, education, health and the provision of sea transportation.

Keywords: Fishermen, Poverty, Islands

\begin{tabular}{ll}
\hline Contact person & $:$ Nurdin Lanuhu \\
Email & $:$ lanuhunurdin@gmail.com
\end{tabular}

\section{PENDAHULUAN}

Kemiskinan merupakan salah satu isu yang menarik khususnya di Indonesia, berbagai definisi, kriteria dan ukuran telah dikemukan untuk menentukan apakah suatu keluarga atau orang tertentu masih termasuk dalam kelompok miskin. Secara umum didefinisikan sebagai tingkat pendapatan minimum untuk dapat memenuhi kebutuhan dasar fisik untuk makanan, pakaian dan perumahan. Secara umum tingkat kemiskinan disuatu Negara sangat ditentukan oleh dua faktor yakni tingkat pendapatan per kapita dan tingkat pemerataan pendapatan, semakin besar ketimpangan pendapatan per kapita semakin besar pula tingkat kemiskinan. Kemiskinan masih merupakan fenomena masyarakat Indonesia yang perlu mendapat perhatian khusus, berbagai pihak seperti kaum cendekiawan, pemerintah, lembaga lembaga internasional dan sebagainya selama ini memberikan perhatian yang cukup besar terhadap masalah ini (Syarifudin Baharsjah, 1991).

Kemiskinan menurut jalur sejarahnya maka kemiskinan adalah akibat bukan sebab, kemiskinan adalah akibat dari kedudukan mereka yang lemah tidak memiliki kemampuan dan kekuasaan untuk mengamankan dan meningkatkan pendapatan padahal mereka perlukan untuk meningkatkan taraf hidup mereka. Kemiskinan dapat terjadi akibat sistim ekonomi yang berlaku karena yang kuat menindas yang lemah, tidak tersedianya pendapatan yang memadai bagi golongan yang bersangkutan, 
struktur pemilikan dan penggunaan tanah, pola usaya yang terkebelang dan sebagainya (Ibnoe Soedjoni, 1991).

Kondisi yang dihadapi oleh nelayan dan menyebabkan mereka tetap miskin sesuai dengan temuan para ahli dapat dikelompokkan berdasarkan sumber dan sifat masalahnya seperti: 1). Sifat dan kondisi lingkungan laut sebagai tempat nelayan melakukan aktivitas kenelayanan yang selalu berubah sesuai dengan perubahan musim dan kondisi lingkungan laut, 2). Keadaan dan kebiasaan ikan yang selalu berubah sesuai dengan perubahan musim dan kondisi lingkungan laut, 3). Struktur sosial yang terbentuk pada masyarakat nelayan cenderung merugikan nelayan yang hanya mengandalkan tenaga. Ketimpangan struktur itu tampak dengan jelas pada pola hubungan kerja dan pola bagi hasil yang selalu merugikan nelayan dan menguntungkan pemilik modal, dan 4). Tingkat perkembangan teknologi nelayan masih sangat sederhana sehingga kemampuan jelajah dan daya tangkap sangat terbatas (Mubyarto, 1985).

$$
\text { Kemampuan nelayan untuk }
$$
memaksimumkan hasil tangkapan ikan ditentukan oleh berbagai faktor antara lain:

1. Modal kerja atau investasi adalah perahu/motor dan jenis alat tangkap.
2. Potensi sumberdaya perairan/daerah operasi penangkapan ikan dilaut.

3. Hari kerja efektif melaut (HKE).

4. Kemudahan untuk memasarkan hasil tangkapan dengan harga yang wajar.

5. Biaya operasi/produksi antara lain minyak, perahu motor, perawatan alat tangkap dan biaya konsumsi waktu melaut (Smith, 1987). Selain hal tersebut diatas, keadaan musim dan lingkungan daerah penangkapan turut mempengaruhi hasil tangkapan para nelayan. Dalam kaitan ini lingkungan kehidupan nelayan sangat tergantung pada sumberdaya perairan, yang hasilnya dapat diambil jika cuaca dan iklim relatif mendukung. Kondisi demikian menyebabkan tingkat pendapatan nelayan tetap rendah (Mubyarto, 1985).

Penggunaan teknologi yang efisien dipengaruhi oleh keterampilan/ pendidikan orang yang menggunakan teknologi tersebut. Selain faktor ekonomi, juga faktor sosial terutama pendidikan dan jumlsh tanggungan keluarga serta umur turut mempengaruhi peningkatkan pendapatan nelayan. Jumlah anggota keluarga yang lebih banyak mendorong mencari nafkah/pendapatan yang lebih pula untuk memenuhi kebutuhan konsumsinya. Teknologi yang lebih maju memberikan keuntungan yang lebih besar bagi nelayan yang menggunakannya, serta 
mendorong mereka memperluas daerah operasinya sehingga bertambah naik pendapatannya Rahim (1985).

Permasalahan kemiskinan Kabupaten Morowali menjadi lebih jelas jika dibandingkan dengan keadaan tingkat provinsi dan nasional. Diketahui, berdasarkan data yang dirilis oleh BPS, perbandingan jumlah penduduk miskin antara Kabupaten Morowali, Provinsi Sulawesi Tengah, dan Nasional menunjukkan bahwa angka kemiskinan Kabupaten Morowali pada tahun 2013 ada sebesar 28,94\%, di mana pada tahun yang sama angka kemiskinan Provinsi Sulawesi Tengah adalah hampir 9\% lebih rendah, bahkan angka kemiskinan nasional kurang dari setengah angka tersebut, yaitu hanya sebesar 11\%. Dengan kata lain, Kabupaten Morowali memiliki indeks kemiskinan lebih besar dibanding wilayah provinsi dan nasional, sekaligus menjadi daerah penyumbang angka kemiskinan, baik di tingkat provinsi maupun nasional (BPS, 2013).

Berdasarkan data bahwa dari 9 kecamatan yang ada di Kabupaten Morowali, terdapat 2 kecamatan yang memiliki jumlah KK miskin sangat tinggi, yaitu Kecamatan Menui Kepulauan dan Kecamatan Bungku Selatan. Dapat dilihat, jumlah KK miskin yang berada di Kecamatan Menui Kepulauan adalah sebesar 1.544 KK, sedangkan di Kecamatan Bungku Selatan adalah sebesar 1.606 KK. Jika digabungkan, maka kedua kecamatan ini memiliki jumlah KK miskin sebesar 3.150, atau $44,8 \%$ dari keseluruhan Kabupaten Morowali. Meski demikian, 2 kecamatan dengan angka kemiskinan terkecil pada kenyataannya masih memiliki angka kemiskinan yang cukup tinggi. Diketahui bahwa 2 Kecamatan dengan jumlah KK miskin terkecil adalah Kecamatan Bungku Pesisir dan Kecamatan Bahadopi, yaitu masing-masing sebesar 356 KK dan 388 KK (Bappeda, 2015).

Berdasarkan uraian permasalahan di atas, maka perlu dilakukan kajian mengenai penyebab kemiskinan di gugus Kepulauan Salabangka Kecamatan Bungku Selatan Kabupaten Morowali Provinsi Sulawesi Tengah. Penelitian ini bertujuan melakukan kajian terhadap faktor-faktor penyebab kemiskinan di gugus Kepulauan Salabangka Kecamatan Bungku Selatan Kabupaten Morowali Provinsi Sulawesi Tengah. Sementara kegunaan yang diharapkan alam penelitian adalah tersedianya data dan informasi faktor-faktor penyebab kemiskinan yang dapat digunakan oleh berbagai pihak dalam menyusun model pemberdayaan masyarakat nelayan dalam penenggulangan kemiskinan di Kabupaten Morowali. 


\section{METODE PENELITIAN}

Penelitian ini dilaksanakan di Gugus Kepulauan Salabangka Kecamatan Bungku Selatan Kabupaten Morowali Propinsi Sulawesi Tengah, pada bulan Juli 2016 sampai dengan Agustus 2016. Lokasi penelitian dipilih secara purposif dengan pertimbangan bahwa Gugus Kepulauan Salabangka Kecamatan Bungku Selatan Kabupaten Morowali penduduknya umumnya bermata pencaharian sebagai nelayan dan memiliki jumlah penduduk miskin yang terbanyak di Kabupaten Morowali.

Penelitian ini didesain dengan menggunakan mixed method approach, dengan menggabungkan Quantitative and Qualitative Research Designs secara simultan.

\section{Sedangkan Qualitative Research Design} menggunakan metode Focus Group Discussion (FGD). Pendekatan ini dilakukan untuk memperoleh data dan informasi yang komprehensif dan saling melengkapi, sehingga situasi di lapangan dapat dideskripsikan dengan baik. Adapun proses tahapan penelitian ini adalah review literatur, kunjungan Lapangan, uji kuisioner dan FGD, pengumpulan data primer dan sekunder.

Kunjungan lapangan ke lokasi studi untuk membangun komunikasi dengan stakeholder dan masyarakat di gugus Kepulauan Salabangka Kecamatan Bungku
Selatan Kabupaten Morowali serta pelaku usaha ekonomi untuk mensosialisasikan rencana kegiatan ini. Dalam kegiatan ini dijelaskan tentang tujuan penelitian, terutama kepada kelompok target, diharapkan terjadinya kesepahaman bersama dan komunikasi dua arah dapat dibangun, sehingga data yang dikumpulkan bisa lebih akurat. Pada kesempatan ini juga dilakukan uji kuisioner dan Pedoman FGD yang telah disiapkan; dilakukan interview sebanyak 5 - 10 tokoh masyarakat.

Data yang digunakan dalam penelitian ini data primer dan data sekunder. Data primer dikumpulkan melalui wawancara terstruktur dengan menggunakan kuisioner dan Pedoman FGD yang telah disiapkan dan diadaptasikan sebelumnya. Pengumpulan data dilakukan oleh peneliti melalui wawancara terstruktur dan FGD bagi stakeholder lokal.

Data primer yang dikumpulkan diedit untuk menjaga konsisten dan akurasi data yang telah dikumpulkan. Kemudian data yang telah diverifikasi akurasinya dianalisis dengan menggunakan Analisis Deskriptif Kualitatif.

\section{HASIL DAN PEMBAHASAN}

$\begin{array}{cr}\text { Gugus Kepulauan } & \text { Salabangka } \\ \text { Kecamatan Bungku Selatan } & \text { Kabupaten } \\ \text { Morowali Propinsi Sulawesi Tengah memiliki }\end{array}$


22 buah pulau dengan jumlah desa sebanyak 24 desa. Secara geografis sebelah utara berbatasan dengan kecamatan bungku pesisir dan perairan teluk tolo, sebelah timur dengan periaran laut banda, sebelah selatan dengan kecamatan menui kepulauan dan wilayah provinsi Sulawesi tenggara dan sebelah arat perairan teluk tolo. Jumlah penduduk sebanyak 13.608 jiwa yang terdiri dari laki-laki 6.781 jiwa dan perempuan 6.827 jiwa. Jumlah Rumah tangga sebanyak 3.124 Kepala Keluarga (BPS, 2016).

Jumlah penduduk berdasarkan tingkat pendidikan dapat dijelaskan bahwa umumnya penduduk di Gugus Kepulauan Salabangka Kecamatan Bungku Selatan berpendidikan Sekolah Dasar (54,1 \%), kemudian SMP/Sederajat (20,3\%), SMA/sederajat (8,6\%), tidak tamat Sekolah Dasar (19,3\%), dan Perguruan Tinggi (0,7 \%).

sJumlah penduduk berdasarkan mata pencaharian umumnya adalah nelayan $(93,1$ $\%)$, sementara sebaran penduduk berdasarkan umur, maka penduduk yang berumur kurang dari 17 tahun sebanyak 18,9\%, penduduk yang berumur 17 tahun sampai dengan 54 tahun sebanyak $56,4 \%$ dan penduduk yang berumur diatas 55 tahun sebanyak 24,7\%.

Masyarakat nelayan di gugus Kepulauan Salabangka Kecamatan Bungku Selatan Kabupaten Morowali dalam operasi penangkapan ikan menggunakan, bagan perahu, pancing, jaring insang hanyut, jaring lingkar, jaring klitik sero, dan bubu.

Bagan perahu dibangun diatas perahu yang sama besarnya. Konstruksi dan peralatan yang dibutuhkan pada dasarnya hampir sama dengan Bagan tancap. Yang membedakan adalah, Bagan perahu tidak ditancapkan di dasar laut, melainkan perahu sebagai pondasi tempat meletakkan kayu sebagai penyangga peralatan lainnya. Bahan bambu seperti yang diperlukan pada Bagang tancap diganti dengan kayu. Lampu diletakkan pada bagianbagian dua perahu yang pada sebelah atasnya sebagian diberi atap sebagai tempat istirahat bagi awak Bagang. Jaring terletak di antara dua perahu yang di atasnya diberi tempat menggantung lampu sebanyak 12 - 14 buah mata lampu. Demikian pula tempat memutar atau menaikan jaring ada pada bagian atas. Dengan demeikian perahu berfungsi sebagai tempat menyangga badan Bagang dan berfungsi sebagai rakit bila Bagang akan dipindahkan beroperasi.

Masyarakat nelayan di Gugus Kepulauan Salabangka Kecamatan Bungku Selatan Kabupaten Morowali mengenal alat tangkap jenis jaring yaitu jaring hanyut dan jaring lingkar. Jaring yang dipasang hanyut disebut dengan jaring hanyut. Jaring insang yang dipasang menetap untuk sementara 
waktu dengan menggunakan alat penahan berupa jangkar yang dipsang pada bagian bawah jaring. Pemasangan jenis jaring ini, oleh masyarakat nelayan dilakukan dengan cara bervariasi tergantung dari jenis ikan yang ditangkap apabila dipasang pada dasar laut, maka ini dimaksudkan untuk menangkap ikan yang ada pada dasar laut, sebaliknya jika dipasang pada permukaan atau pertengahan air laut, ini dimaksudkan untuk menangkap ikan jenis tertentu yang biasanya hidup pada bagian permukaan laut.

Proses pengoperasian jenis alat tangkap ini adalah, nelayan memasangnya disuatu tempat yang dipilih berdasarkan keyakinan bahwa di tempat itu banyak terdapat ikan berdasarkan tanda-tanda yang mereka ketahui. Setelah dipasang, nelayan meningggalkannya untuk beberapa waktu kemudian dating mengangkat jaring dan sekaligus mengambil ikan yang sangkut. Setelah itu nelayan memasangnya kembali dan membiarkan untuk jangka waktu seperti tersebut di atas dan nelayan akan kembali mengangkat dan mengambil hasilnya. Biasa pula terjadi bahwa, nelayan mengangkat dan mengambil hasilnya hanya satu kali sehari yaitu pada waktu pagi hari, yang dipasang pada waktu sore hari kemarinnya. Jenis ini biasanya dipasang didekat pesisir pantai. Jenis ikan yang biasa ditangkap adalah balana, bete-bete dan lain-lainnya.

Jenis lain dari laat tangkap jaring ini adalah, jaring insang hanyut. Bentuknya persegi empat panjang dan dilengjapi dengan pemberat-pemberat pada tali ris bawah dan pelampung pada ris tali atasnya. Jenis jaring ini dipasang tegak lurus di dalam air dan menghadang arah gerak ikan.Ikan tertangkap karena tersangkut pada mata jaring atau tergulung oleh jaring tersebut.

Jenis jaring insang hanyut, adalah jaring insang yang pemasangnya dibiarkan hanyut mengikuit arus. Salah satu ujungnya dibiarkan lepas, sedangkan yang satunya diikatkan pada perahu. Jaring ini dimaksudkan untuk menangkap jenis ikan permukaan. Proses pengoerasiannya sama dengan jenis jaring tetap seperti yang dikemukakan di atas, hanya saja jenis jaring ini tidak menetap pada suatu tempat tertentu.

Pada umumnya nelayan yang memilih jenis alat tangkap ini sebagai alat operasi hanya disebabkan karena kekurangan modal usaha. Nelayan menyadari bahwa, hasil yang diperoleh dengan menggunakan jenis alat tangkap jaring jauh lebih rendah jika dibandingkan dengan menggunakan alat tangkap lain seperti Bagang, pancing dan pukat cincing. Akan tetapi, kemampuan untuk membeli alat-alat tangkap seperti tersebut di 
atas tidak ada, maka nelayan terpaksa hanya menggunakan alat tangkap jenis ini, dengan harapan agar pada suatu waktu, nelayan itu dapat memiliki alat tangkap yang lebih produktif. Alat tangkap ini menurut pengakuan nelayan yang menggunakannya mudah diperoleh, karena mereka hanya membeli bahannya berupa tali plastik dan tali tasi. Proses pembuatannya dilakukan sendiri dengan merajut. Pelampungnya dibuat sendiri dari bahan bekas sandal jepit, sedangkan pemberatnya terbuat dari timah putih.

Alat tangkap lainnya adalah bubu yaitu perangkap yang mempunyai satu pintu masuk dan dapat diangkat dengan muda. Alat ini diletakkan oleh nelayan pada dasar laut yang dangkal dan dapat diangkat setelah sehari sesudahnya. Alat ini sebenarnya, diakui oleh nelayan setempat kurang produktif dan hanya dilakukan oleh nelayan berskala kecil. Jenis alat tangkap in termasuk paling pasif karena hanya tinggal menetap dalam suatu tempat tertentu menanti adanya ikan yang masuk. Ikan yang masuk ke dalam bubu tidak dapat keluar lagi, karena mulut yang mengarah keluar diberi penghalang Alat ini terbuat dari bambu/kawat yang dirakit sedemikian rupa sehingga memungkinkan dimasuki kawanan ikan dan tidak dapat keluar lagi. Jenis yang lain dari alat tangkap perangkap yaitu sero. Jenis alat inipun pasif karena dipasang dipinggir pantai menghadap ke darat, dimaksdukan menangkap ikan dipesisir pantai.

Nelayan di gugus Kepulauan Salabangka Kecamatan Bungku Selatan Kabupaten Morowali mengenal adanya beberapa macam pancing, yang disesuikan dengan penggunannya yaitu: a) Jenis pancing yang dioperasikan pada waktu sore menjelang malam. Kegiatan pancing ini dengan kegiatan mencari umpan berupa ikan-ikan kecil, dilakukan pada wilayah yang airnya sedang. Jenis ikan yang menjadi pancing adalah ikan kembung, laying, dan lain-lain. Setelah mendapatkan ikan umpan, perjalanan dilanjutkan sampai pada perairan laut "dalam" untuk memancing. Pada pangkal mata pancing dipasang benda yang berkilau (biasanya dgunakan bulu ayam jantan/tali rapiah/benang), yang dimaksudkan menarik perhatian ikan-ikan besar yang akan ditangkap. Jenis ikan yang biasa ditangkap adalah semua jenis ikan yang berukuran besar seperti ikan sunu, ikan pari, ikan tuna, dan lainb) Pancing Tonda yakni pancing bentuknya saling mengikat. Dilihat dari bentuknya, pancing ini memiliki banyak mata pancing (pada umumnya mencapai 200 sampai 300) yang antara satu dengan lainnya saling mengikat dengan jarak kira-kira $20 \mathrm{~cm}$. Dalam pengoperasiannya tidak menggunakan umpan, melainkan hanya menggunakan 
benda-benda yang menarik perhatian ikan, seperti bulu ayam, tali rapiah. Waktu pengoperasian alat ini sangat tergantung pada kondisi dan kesempatan nelayan, baik pada malam atau siang hari. Jenis ikan yang ditangkap yaitu ikan kembung, layang, tembang dan lain-lain.

c). Pancing Cakalang yaitu jenis pancing yang hanya diperuntukkan untuk menangkap ikan cakalang. Ikan cakalang yang dipancing diusahakan naik pada permukaan laut. Cara menaikkan ke permukaan laut adalah, diantara kawanan pemancing bertugas membuang ikan kecil ke dalam laut untuk menarik ikan cakalang naik ke permukaan laut atau mengikuti arah ikan lumba yang sementara bergabung dengan ikan cakalang.

\section{Faktor Faktor Penyebab Kemiskinan}

Hasil analisis data menunjukkan bahwa terdapat beberapa faktor internal dan eksternal yang menyebabkan kemiskinan tetap terjadi walaupun sudah puluhan bahkan ratusan tahun masyarakat nelayan di gugus kepulauan Salabangka mampu bertahan hidup dengan cukup baik, namun hingga penelitian ini selesai dilaksanakan angka kemiskinan masih cukup tinggi. Adapun faktor-faktor yang menyebabkan terjadinya kemiskinan di wilayah gugus Kepulauan
Salabangka Kecamatan Bungku Selatan dapat diuraikan sebagai berikut:

\section{Keadaan Musim}

Keadaan musim yang tidak menentu yang dihadapi oleh nelayan menyebabkan para nelayan berada pada ketidakpastian pendapatan. Di gugus kepulaun Salabangka dalam setahun hanya dapat melakukan penangkapan secara efektif selama kurang lebih 6 (enam) bulan yakni pada bulan Oktober sampai dengan bulan Maret, sedang dari Bulan April sampai dengan bulan September nelayan sangat terbatas melakukan aktifitas melaut bahkan bagi nelayan yang memiliki fasilitas yang sederhana tidak melakukan aktifitas melaut dengan kata lain mereka menganggur, hal disebabkan pada bulan April sampai dengan bulan September terjaadi angin kecang dengan tinggi gelombang 4-5 meter.

Kondisi seperti ini sangat mempengaruhi pendapatan dalam membiayai kehidupan keluarga, apalagi selama enan bulan mereka melakukan penangkapan dengan hasil yang kurang serta tidak dapat menabung untuk keperluan sehari-hari, maka pada saat tidak melaut selama enam bulan kehidupan merka sangat tergntung pada pemilik modal dengan cara melakukan pinjaman baik berupa bahan 
makanan maupun uang untuk keperluan keluarga seperti biaya sekolah.

Perubahan musim mempangaruhi sifat dan kondisi lingkungan laut sebagai tempat nelayan melakukan aktivitas kenelayanan yang selalu berubah juga menyebabkan keadaan dan kebiasaan ikan yang selalu berubah sesuai dengan perubahan musim dan kondisi lingkungan laut. Perubahan musim ini sangat berpengaruh pada hasil tangkapan nelayan yang selanjutnya berpengaruh pada penerimaan dan pendapatan nelayan. Hal lain adalah adanya pola migrasi dan kebiasaan ikan bervariasi menurut keadaan iklim dan kondisi air laut, menyebabkan sulit bagi nelayan menentukan strategi penangkapan karena para nelayan pada umumnya belum banyak memiliki pengetahuan yang berhubungan dengan potensi ikan dilaut.

\section{Struktur Sosial}

Struktur sosial yang terbentuk pada masyarakat nelayan cenderung merugikan nelayan yang hanya mengandalkan tenaga. Ketimpangan struktur itu tampak dengan jelas pada pola hubungan kerja dan pola bagi hasil yang selalu merugikan nelayan dan menguntungkan pemodal. Pada dasarnya struktur sosial yang ada pada masyarakat nelayan, menyebabkan tidak berdaya melawan eksploitasi kaum tengkulak dan pemilik modal yang seenaknya mempermainkan harga. Keadaan ini diperburuk oleh sistem dan pola bagi hasil yang merugikan nelayan. Kenyataan menunjukkan bahwa, sampai saat ini kaum nelayan dengan segala kekurangannya, tetap bertahan pada sektor laut sebagai sumber pencaharian, walaupun dalam batas yang marginal dan subsisten.

Berdasarkan hasil penelitian diperoleh bahwa suatu kelompok operasi penangkapan ikan di daerah penelitian ditemukan beberapa pola atau tipe yakni:

1) Suatu kelompok penangkapan hanya terdiri dari dua unsur yaitu pemilik modal dengan para sawi. Kedua unsur ini terikat dalam suatu ikatan kerjasama yang bersifat ekonomi. Sawi memperoleh pendapatan dari sejumlah bagi hasil dari keseluruhan tangkapan untuk setiap periode operasi. Pemilik modal bertindak sebagai juragan yang bertanggungjawab terhadap operasi penangkapan, misalnya pada Bagang

2) Suatu kelompok terdiri dari unsur pemilik modal, juragan dan sawi. Pemilik modal tidak terlibat dalam operasi penangkapan ikan, tetapi hanya memasok modal. Sementara yang bertanggung jawab dalam operasi penangkapan adalah juragan dan buruh yang bekerja adalah sawi. Hal yang 
membedakan dengan pola atau tipe yang pertama adalah Pemilik Modal mempunyai kewenangan mengatur harga ikan di pasaran dan juragan tidak berdaya untuk mencegahnya karena takut tidak diberi kepercayaan oleh pemilik modal sebagai juragan, misalnya pada kapal pancing cakalang.

3) Suatu kelompok dalam usaha penangkapan ikan yang tetap menggunakan istilah juragan-sawi tetapi dalam operasional dan hubungannya tidak seperti pada pola pertama dan ke dua. Kelompok ini pemilik modal sekaligus mengoperasikan yang dibantu oleh anggota keluarganya sendiri (anak), misalnya pada pancing cakalang, dan bubu.

4) Suatu kegiatan unit penangkapan ikan yang dilakukan secara individu yakni dilakukan secara perorangan misalnya pancing ikan dasar laut, dan cumi-cumi.

Berdasarkan tipe atau pola penangkapan tersebut, maka sistim bagi hasil ditemukan beberapa sistim yakni:

\section{Sistem Pertama}

1. Semua komponen biaya yang digunakan dalam proses operasi penangkapan ikan dihitung, kemudian di keluarkan dari nilai produksi.

2. Pendapatan bersih dibagi tiga bagian besar yakni satu bagian untuk pemilik alat tangkap dan kapal motor, satu bagian untuk juragan, dan satu bagian untuk sawi.

3. Satu bagian untuk sawi dibagi sesuai dengan banyaknya sawi.

4. Struktur pembagian hasil seperti ini apabila juragan adalah ekaligus pemilik alat tangkap dan kapal motor, maka mendapatkan 66,7 persen dari total pendapatan bersih Sementara sawi hanya mendapatkan 33,3 persen. Dengan demikian makin banyak jumlah sawui makin kecil pendapatan yang diperoleh masing-masing sawi.

\section{Sistem Kedua}

1. Semua komponen biaya yang digunakan dalam proses operasi penangkapan ikan dihitung, kemudian di keluarkan dari nilai produksi.

2. Dari pendapatan bersih, pemilik rumpon mendapatkan 15 persen.

3. Sisanya 85 persen dibagi menjadi satu bagian untuk Juragan, dua bagian untuk kapal motor beserta jaringnya, dan sawi masing satu bagian.

4. Apabila juragan bukan pemilik kapal dan jaring, maka juragan mendapatkan bonus dari pemilik kapal dan jaring sebesar 10-15 persen dari pendapatan pemilik kapal motor dan jaring. 


\section{Sistem Ketiga}

1. Semua komponen biaya yang digunakan dalam proses operasi penangkapan ikan dihitung, kemudian di keluarkan dari nilai produksi.

2. Dari pendapatan bersih, pemilik kapal motor mendapatkan satu bagian, juragan mendapatkan 1,5 bagian, sawi masingmasing satu bagian.

Apabila sistim bagi hasil tersebut dikaitkan dengan kemiskinan, maka sistim pertama merupakan sistim yang sangat merugikan nelayan sebagai sawi dan dapat dikatakan bahwa pada sistim ini pemilik modal menciptakan ketergantungan sehingga seorang sawi tetap dalam keaadaan miskin selama hidupnya, sementara sistim ketiga masih lebih baik dibanding dengan sistim kedua dan pertama serta sistim kedua lebih baik dari sistim pertama

\section{Pengeloaan Pendapatan.}

Hasil penelitian menunjukkan bahwa pada umumnya nelayan tidak dapat mengelola pendapatan dengan baik. Hal ini terlihat bahwa dari data yang dikumpulkan para nelayan dalam pengelolaan keuangan keluarga sangat lemah dimana sebagian besar pendapatan yang diperoleh dibelanjakan atau dihabiskan untuk konsumsi. sehingga para nelayan tidak memiliki tabungan. Kenyataan ini sebenarnya karena dikecamatan ini tidak terdapat bank sehingga masyarakat tidak terbiasa menabung, selain itu para nelayan juga beranggapan bahwa kalau sudah turun dilaut Allah S.W.T selalu memberikan rejeki dengan mudah walaupun jumlahnya tidak memadai. Keadaan inilah yang memperburuk kondisi kesejahteraan masyarakat, sehingga masyarakat nelayan tetap berada pada kategori miskin.

\section{Pencemaran Lingkungan}

Sejak adanya usaha pertambagan nikel di wilayah Kabupaten Morowali, khusunya di Gugus Kepulauan Salabanga Kecamaatan Bungku Selatan, kualitas air diperairan mulai menurrun dimana pada setiap terjadi hujan selalu diikutti dengan banjir yang menyebabkan terjadinya pencemaran lingkungan di laut.

Akibat dari pencemaran lingkungan ini menyebabkan. Ekosistem laut yang semula sangat potensial sebagai tempat tumbuh dan berkembang biak ikan dan rumput laut menjadi terganggu. Hal ini diperjelas dengan berkurangnya hasil tangkapan ikan para nelayan serta menurunnya kesuburan penanaman rumputt yang berakibat pada menurunnya produksi bahkan rumput laut mati dibeberapa pulau yang dekat dengan 
daratan atau lokasi pertambangan nikel Perusahaan Nikel sudah pernah memberikan ganti rugi kepada nelayan dan pembudidaya rumput laut, namun tidak sesuai dengan kerugian yang diakibatkan oleh pemcemaran lingkungan akibat aktifitas pertambangan

\section{Pelayanan Pemerintah}

Pelayanan pemerintah yang berakibat kemiskinan masih tetap tinggi di Gugus Kepulauan Salabangka Kecamatan Bungku Selatan adalah pelayanan pemerintahan, pelayanan kesehatan, pelayanan pendidikan serta penyediaan dsarana dan prasarana transportasi. Hasil kajian menunjukkan bahwa pelayanan pemerintah khusunya camat diwilayah kecamatan bungku selatan masih rendah. Akibat tingkat kehadiran Camat cukup rendah pada desa desa yang membutuhkan dukungan dari camat berimplikasi kepada tidak terfasilitasinya semua porgram pengentasan kemiskinan dengan baik. Demikian pula pelayanan pendidkan di gugus Kepulauan Salabangka Kecamatan Bungku Selatan masih sangat rendah terutama pada penyediaan sarana pendidikan tidak mencukupi untuk tingkat SMP dan SMU. Apalagi perguruan tinggi, baik dari segi kuantitas maupun jarak. Akibatnya, masyarakat harus mengeluarkan biaya mahal untuk mendapatkan pendidikan, misalnya biaya untuk transportasi laut atau berkuliah di Bungku, Kendari, Palu atau Makassar, sehingga masyarakat apabila sudah menamatkan pendidikan maka mereka tidak melanjutkaan pada jenjang yang lebih tinggi. Demikian pula pada pelayanan kesehatan dimana fasilitas yang disiapkan untuk memberikan pelayanan kepada masyarakat sangat terbatas baik dari jumlah tenaga dan fasilitas kesehatan serta kesadaran terhadap pentingnya aspek kesehatan sehingga masyarakat yang berdiam di wilayah ini harus mengeluarkan biaya tambahan dan menempuh jarak yang cukup jauh untuk mengakses fasilitas danpelayanan kesehatan terdekat. Akbiatnya masyarakat lebih memilih untuk tidak berobat dan mengeluarkan biaya untuk kesehatan. Hal ini selain fasilitas kesehatan yang jauh, juga mereka ttidak memiliki biaya untuk berobat walaupun pemerintah memberikan ppengobatan gratis tetapi biaya transportasi dan biaya lain-lain dalam proses pengobatan di puskesma/rumah sakit tidak ditanggung oleh pemerintah.

\section{KESIMPULAN DAN SARAN}

Hasil Penelitian menunjukkan bahwa beberapa faktor yang mennyebabkan kemiskinan di Gugus Kepulauan Salabangka Kecamatan Bungku Selatan Kabupaten Morowali Provinsi Sulawesi Tengah adalah 
Keadaan Musim, Struktur Sosial, Pengelolaan

Pendapatan, Pencemaran Lingkungan dan

Pelayanan Pemerintah dibidang

pemerintahan, pendidikan, kesehatan dan sarana prasarana tranportasi.

Guna mengentaskan kemiskinan maka direkomendasikan 1) Pengembangan ekonomi kerakyatan berbasis potensi lokal, 2) Perbaikan pelayanan pemerintah dalam bidang pemerintahan, pendidikan, kesehatan dan penyediaan sarana transportasi laut

\section{DAFTAR PUSTAKA}

Bappeda, 2015. Pemetaan dan Penyusunan Road Map Kemiskinan Kabupaten Morowali, Kantor Bappeda Kabupaten Morowali Provinsi Sulawesi Tengah.

Biro Pusat Statistik Kabupaten Marowali, 2015.

Marowali Dalam Angka. Kantor Statistik Kabupaten Marowali Propinsi Sulawesi Tengah.

Biro Pusat Statistik Kabupaten Marowali, 2015.

Kecamatan Bungku Selatan Dalam Angka. Kantor Statistik Kabupaten Marowali Propinsi Sulawesi Tengah.
Ibnoe Soedjono, 1991. Strategi Kebijakan Pembangunan Pemerintah Dalam Penanggulangan Kemiskinan. Makalah Seminar Nasional, Bogor.

Mubtyarto, 1985. Nelayan dan Kemiskinan, Studi Ekonomi dan Antropologi di Dua Desa Pantai Jawa Tengah. Yayasan Agro Ekonomika dan CV. Rajawali, Jakarta.

Nicholson, Walter, 1987. Micro Economic Intermediate dan Penerapannya. Erlangga, Jakarta.

Rahim Manat, 1994. Faktor Ekonomi dan Sosial Yang Mempengaruhi Pendapatan Nelayan di Kabupaten Buton. Tesis Unpad, Bandung.

Syarifudin Baharsyah, 1991. Kebijakan pembangunan Pertanian dalam Rangka Penanggulangan Kemiskinan. Makalah Seminar Nasional, Bogor.

Smith, Ian R., 1987. Peningkatan Pendapatan Perikanan Pada Sumberdaya Yang Lebih Tangkap, Ekonomi Perikanan. Yayasan Obor Indonesia, Jakarta.

Tohir, Kaslan. A, 1987. Pengantar Ekonomi Pertanian. NV. Penerbit W. Van Hoeve, Bandung. 